\title{
PLURALISME DAN DIALOG ANTAR AGAMA
}

\author{
Abdul Halim \\ Fakultas Ushuluddin IAIN STS Jambi
}

\begin{abstract}
Abstrak: Kemajemukan atau yang lebih dekat dengan sebutan pluralisme, di satu sisi menjadi khazanah budaya bangsa yang terus haras terjaga. Jika agama merupakan bagian dari khazanah budaya bangsa dengan nilai-nilai keberagamaan pemeluknya masingmasing, maka sisi lain harus diwaspadai adalah konflik atau ketegangan yang terjadi akibat persentuhan antara nilai-nilai suatu agama dengan nilai-nilai agama lain yang sangat dipengaruhi oleh individu-individu pemeluk masing-masing agama. Dalam hal ini terdapat kecenderungan penganut masing-masing agama untuk memuliakkan bentuk-bentuk tertentu dari agamanya sehingga agama itu menjadi tertutup atau yang kita kenal dengan sikap keberagamaan yang ekslusivistis, dimana hubungan timbal balik antara agama dan situasi sosialnya menjadi macet dan tidak harmonis, padahal agama berbubungan dengan sesuatu yang dianggap ilahi atau mutlak, dengan sendirinya agama itu mestinya memandang dirinya sendiri (dengan segala ajaran, upacara, perilaku keagamaan pemeluknya, dan lain-lain) sebagai hal yang bersifat lelatif dan tidak mutlak.
\end{abstract}

Kata kunci: Pluralisme, Toleransi, Dialog Antar Agama

\section{Pendahuluan}

Pemutlakan bentuk-bentuk tertentu dari suatu agama yang menyebabkan agama tersebut menjadi tertutup, dilegitimasi oleh kekuatau elit-elit agamawan masing-masing agama, dimana didalamnya terdapat kepentingan-kepentingan yang saling berkelindan, Implikasi dari kesemuanya ini adalah pembekuan kemutlakan tesebut atau yang dikenal dengan sakralisasi ajaranajaran agama. Pada akhirnya sikap jenuhpun muncul, ada keinginan untuk bebas dan lepas dari kungkungan kejiwaan yang diikat dengan ketat sekali oleh agama tersebut, Al-hasil, kondisi yang telah membeku tersebut dipecahkan dan dirombak oleh suatu revolusi spiritual ${ }^{1}$ yang terayata melahirkan suatu proses perjalanan

\footnotetext{
${ }^{1}$ Fachry Ali, Islam, Pancasila..., p. 188.
} 
yang teramat panjang dan mampu mengubah peta sejarah saat ini.

Revolusi spiritual adalah awal dari kebangkitan revolusi ilmu pengetahuan. Kebebasan untuk mengemukakan pendapat, keberanian mengkritik teks-teks lama, pemberontakan terhadap sakraliasi teks keagamaanpun semakin kuat, sikap keberagamaan yang selama ini tertutup (ekslusif) dinilai sebagai kekeliruan dari interpretasi teks-teks agama, kelompok-kelompok tertentu dalam masing-masing agama mulai membuka diri, kecenderungan bersikap terbuka dalam beragama pun mulai jadi pilihan. Ada semacam pergeseran paradigma sikap beragama dalam masingmasing pemeluk agama, dari sikap ekslusivistis kepada inklusivistis.

Sikap ekslusif dalam beragama cenderung menutup diri dan berupaya untuk memutlakkan ajaran agama. Mereka mengklaim bahwa dirinya adalah penerus tradisi agama yang sah dan tak berkeputusan, walaupun sebenarnya mereka juga sedang mentransformasikan tradisi-tradisi itu sendiri. Anggapan mereka adalah bahwa cara beragama merekalah yang paling baik dan sah. Keprihatinan yang mendalam terhadap nilai-nilai normatif yang selama ini dipegang teguh membuat mereka menghindari dan menolak untuk melegitimasi budaya-budaya yang bertentangan dengan budaya yang mereka yakini sebagai kebenaran fundamental. ${ }^{2}$ Dalam hal ini dialog bukanlah sesuatu yang mendapat respek positif dari mereka, tetapi justru sebaliknya akan mengakibatkan pendangkalan agama (nilai-nilai keberagamaan). Lain halnya dengan sikap inklusif, karena terlalu membuka diri, akhirnya mereka hampir kehilangan identitas sebagai pemeluk satu agama, dan inilah yang dinamakan bahwa mereka sedang dalam kebingungan teologis. ${ }^{3}$

Pergeseran sikap beragama yang menurut saya juga berimplikasi terhadap fluktuasi nilai-nilai keberagamaan yang selama ini diyakini, atau dengan kata lain, berpengaruh terhadap sistem nilai dalam agama yang mereka anut, sebenarnya menjadi problem bagi agama yang harus dipecahkan dan memposisikan dialog sebagai suatu yang seyogyanya diterima oleh semua pihak.

2 John Ketsay dan Summer B. Twis, Agama dan Hak-hak Asasi Manusia, terjemahan Ahmad Suaedy dan Elga Sarapung, (Yogyakaita: Dian Interfei, 1997), p. 34.

3 Baca: Komaruddin Hidayat dan M. Wahyuni Nafis, Agama Masa Depan: (Jakarta: Paramadina, 1995), pp. 123-129. 


\section{Dialog dan Problem Agama-agama}

Sebelum memperbincangkan masalah dialog, terlebih dahulu di sini saya ingin memaparkan tentang "agama" an sich terlebih dahulu, yang akan mengantarkan kita kepada perlunya dialog tersebut untuk dilakukan. Dengan menggunakan teori tiga dimensi kasunyatan (subyektif, obyektif, dan simbolik), maka agama dapat diletakkan ke dalam tiga level di atas; agama subyektif yaitu kesadaran atau iman, dalam terminologi lain yang lebih populer adalah aqidah (bagi umat Islam), agama obyektif yaitu kelakuan atau amal, atau yang dikenal dengan akhlaq, dan agama simbolik yaitu ajaran atau ilmu, yang disebut juga dengan syari'at. ${ }^{4}$

Ketiga dimensi kesunyataan tersebut tidak dapat dipisahkan antara satu dengan yang lain. Level pertama adalah kepasrahan rohani dan bersifat azali (sangat pribadi), sedangkan level kedua merupakan realitas kehidupan manusia yang agung. Adapun level ketiga hanya akan muncul karena kehadiran dua level sebelumnya, oleh karena itu agama simbolik punya peran strategis dalam mentransformasikan satu level ke level yang lain. Dia tidak bersifat historis sebagaimana level pertama dan kedua, tetapi lebih bersifet nisbi dan normatif, terpengaruh oleh ruang dan waktu, sebab itu, ajaran suatu agama sering mendapat interpretasi kultural maupun sosial dalam perjalanan sejarahnya. Namun karena simbolisnya, para penganut agama tesebut sering terkecoh dan menganggapnya sebagai agama keseluruhan. Agama simbolik inilah yang telah melahirkan simbol beraneka ragam. Agama simbolik lebih ekslusif, tertutup sehingga keberadaan sesuatu di luar kemutlakan yang direkamnya dianggap sebagai musuh. Dengan kata lain agama simbolik adalah agama konflik. ${ }^{5}$ Di sinilah letaknya perlu dialog.

Secara harfiah kata dialog bermakna "Conversational discussion in which two or more take part, whether in actual life or in literary production" atau juga diartikan "synonim of conversation" $^{6}$ (Dialog selain bermakna synonim dengan

${ }^{4}$ Lihat: Masdar Farki Mas'udi, Agama dan Dialognya, dalam Dialog: Kritik dan Identitas Agama, pp. 151-153. Bandingkan dengan: Ajaran Hukum Kesunyatan dalam Agama Budha yang membaginya kepada Triloka atau Tugas Alam. Oka Dqaitra, dkt, Kuliah Agama Budha untuk Perguruan Tinggi, (Jakarta: YASADARI, 1996), pp. 67-70.

5 lbid., p. 155.

${ }^{6}$ Lihat; Charles Earle Funk (ed.), New Practical Standard Dictionary, VoL A-P (New York: Funk and Wagnalls Company, 1955), p. 367_ 
konversation, juga berarti diskusi konvensional baik tentang kehidupan aktual maupun dalam bentuk yang bersifat literal).

Selain itu, dialog juga diartikan sebagai pertukaran pikiran dengan maksud supaya pendapat/ keyakinan masing-masing pihak semakin jelas, sehingga dapat dipahami (bukan hanya diketahui) dengan lebih tepat, keyakinan lain dihormati, meskipun tidak selalu dapat diterima. Oleh karena itu menurut Heuken dialog hanya berguna jika pihak-pihak yang bersangkutan bersedia mendengarkan dan mempertimbangkan uraian dan alasan pihak lain serta berusaha menempatkan diri dalam posisi sebagai patner dialog untuk mencari kepentingan bersama bukan kepentingan kelompok. Sebab itu dialog ada banyak macamnya; Dialog karya mencakup kerjasama dalam proyek kemansiaan (doa bersama, meditasi). Dialog tematis: berbincang tentang tema yang disepakati semua pihak. Dialog informal/kehidupan: di sini perlu kerukunan, dialog formal (dengan pokok-pokoktertentu). ${ }^{7}$

Di dalam bahasa Arab kata dialog lebih tepat diartikan sebagai "Hiwar" yang bermakna pertemuan antar agama yang memperhatikan tujuan umum dari segala agama, yakni memasyhurkan nama Allah. Sedangkan "Tahaddi" terdapat unsur mengkonversi pihak iain. ${ }^{8}$ Menurut Mukti Ali, dialog antar agama adalah pertemuan hati dan pikiran antar pemeluk berbagai agama. Dialog adalah komunikasi antara orang-orang yang percaya pada tingkat agama. Dialog merupakan jalan bersama untuk mencapai kebenaran dan kerjasama dalam proyek-proyek yang menyangkut kepentingan bersama. ${ }^{9}$

Dalam tingkatan agama, dialog menuntut supaya setiap pihak dalam dialog mengharuskan adanya kebebasan beragama, hingga setiap orang bebas untuk menguraikan pandangannya kepada orang lain dan membiarkannya menyampaikan pandangannya kepadanya. Dengan itu akan menjadi jelas persamaan dan perbedaan ajaran

Bandingkan dengau: Kata Dialog or Dialogue. A. Meriem Webster, Webster's third New International Dictionary, VoL I, (London: C. Meriam, Co., 1981), p. 623. Juga lihat: Lexicon Universal Encyclopedia, (New York: Lexicon Publication Inc. 1989), p. 372.

${ }^{7}$ Adolf Heuken Sj., Ensiklopedi Gereja I, A-G, (Jakarta: Yayasan Cipta Loka Caraka, 1991), pp. 240-241.

${ }^{8}$ Ibid

${ }^{9}$ Lihat: Mukti Ali, Ilmu Perbamdingan Agama, Dialog, DaKwah dan

Misi, dalam Buhanuddin Daya dan Herman Leonard Back (edj, ilmu Perbatidingan Agama...p. 208, 
satu agama dengan ajaran agama lain. Selain itu, dialog juga membiarkan utuh hak setiap orang untuk mengamalkan keyakinankeyakinannya dan menyampaikannya kepada orang lain. Dialog antar agama adalah suatu perjumpaan yang sungguh bersahabat dan berdasarkan hormat dan cinta dalam tingkatan antar pemeluk agama. ${ }^{10}$ Banyak orang memahami "dialog" ketika dua orang terlibat perbincangan satu sama lain. Mukti Ali berpendapat bahwa sub kata "dia" dalam "dialog" tidak mempunyai sesuatu untuk dikerjakan dengan "duo" pihak kedua, Sebenarnya, dialog berarti "dia-leghe" yaitu yang sedang berbicara, sedang berdiskusi, sedang beralasan mengenai seluruh aspek persoalan, Karenanya saling mengoreksi dan bergerak bersama-sama dengan kata "concourse", yang berarti berlari bersama, bergerak bersama, bergerak maju bersama, bukan hanya bicara satu dengan yang lain. ${ }^{11}$

Barangkali kita dapat menerima kalau dialog diartikan ketika dua orang terlibat perbincangan satu sama lain sebagai pengertian awal. Namun ketika dialog diangkat dalam permukaan yang universal maka akan melibatkan banyak masalah dan berbagai pihak. Dialog tidak lagi diartikan diskusi atau pemecahan masalah secara bersama-sama antara Islam dan Kristen, tetapi ingin melibatkan agama-agama lain dan berbagai aspek persoalan. Sehingga dialogpun muncul dalam berbagai bentuknya. Seperti; dialog kehidupan, dialog perbuatan, dialog teologis, dialog pengalaman agamis, dan dialog antar monastik ${ }^{12}$, serta lainnya. Kendati demikian, bukan berarti pengertian awal di atas hilang atau tidak berlaku lagi, tetapi justru persyaratan dialog diambil dari pengertian tersebut.

Jika dua orang terlibat dalam suatu perbincangan, biasanya hal-hal yang diangkat erat kaitannya dengan masalah pribadi masing-masing, lebih rahasia, dan tertutup. Dalam kondisi seperti ini, kedua belah pihak akan terbawa kedalam emosi masingmasing, tanpa sadar keduanya menyatakan dengan kejujurannya dan saling terbuka. Contoh praksisnya adalah jika dua orang dewasa yang saling cinta, akan dengan jujur mengungkapkan

${ }^{10}$ lbid., p. 209.

${ }^{11}$ Mukti Ali, Agama, Moralitas dan Perkembangan Kontemporer, dalam Mukti Ali, dkk, Agama dalam Pergumulan Masyarakat Kontemporer, (Yogyakarta; Tiara Wacana, 1997), pp. 7-8.

${ }_{12}$ Mukti Ali, Islam dtm Pluralitas Keberagamaan di Indonesia, dalam Nurhadi M. Musawir(ed).,,,pp. 117-118. 
perasaan masing-masing, atau seorang Kristiani yang menghadap pastornya untuk pengakuan dosa, dan seorang muslim yang sholat di tengah malam mengungkapkan seluruh kejujurannya kepada Tuhannya, prinsip dasar yang dapat diambil adalah kejujuran. Kejujuran dalam berdialog, seagaimana yang dikatakan oleh Mukti Ali bahwa dialog menuntut sikap seimbang, hants jujur tetapi tidak melampaui batas dalam pemikiran kritis. Terbuka dan suka menerima serta mendengarkan pendapat orang lain. ${ }^{13}$

Melakukan dialog tidak semudah membalikkan telapak tangan, karena dialog itu perlu dilakukan demi terwujudnya kehidupan beragama yang rukun, agar ketegangan dan konflik yang terjadi antar pemeluk agama, minimal dapat berkurang. Tetapi ada beberapa hal yang menjadi kesulitan dalam melakukan dialog terutama dalam lapangan teologis. Dan ini menjadi problem serius bagi masingmasing agama yang ingin berdialog, Beberapa problem tersebut antara lain: Pertama: hal-hal yang erat kaitannya dengan doktrin agama (berdasarkan kitab masing-masing agama) yang bersifat absolut ekslusif, seperti di dalam Islam terdapat banyak ayat-ayat ekslusif yang berujung kepada ajaran jihad dan mati syahid. Begitu pula terdapat di dalam ajaran Kristen yang menyatakan bahwa keselamatan hanya ada datam eereja. Extra Ecclessiam Nulla Solus. ${ }^{14}$ Kedua: Masalah kebebasan beragama, prinsip kebebasan atau kemerdekaan beragama itu berisi pengakuan dan jaminan bahwa setiap orang bebas dan merdeka menganut agama yang diyakininya. ${ }^{15}$ Di dalam Islam kebebasan agama mendapatkan tempat sebagai pengakuan teihadap manusia itu sendiri yang juga merupakan hak paling asasi berasal dari Tuhan.

Dalam konteks Indonesia yang plural religi, kebebasan agama mendapatkan jaminan secara konstitusional oleh negara. Terdapat dalam pasal 29 ayat 2 Undang-Undang Dasar 1945 bahwa negara menjamin kemerdekaan tiap-tiap penduduk untuk memeluk agamanya masing-masing dan untuk beribadat menurut agama dan kepercayaannya itu.

Pada dasarnya setiap orang atau kelompok berhak untuk

${ }^{13}$ Ibid.

${ }^{14}$ A. Heuken SJ, Etisildopedi Gereja-p. 315

15 Johan Efendy, Jaminan Konstitusional Bagi Kebebasan Beragama di Indonesia, dalam Komaruddin Hidayat dan Ahmad Gaus AF (ed.). Passing Over Melintasi Batas Agama, (Jakarta: Gramedia Pustaka Utama dan Paramadina, 1998), p. 118. 
menanggalkan dan meninggalkan aliran atau agama yang dianutnya lalu kemudian memeluk aliran atau agama lain yang diyakininya cocok. Kebebasan betukar agama itu dalam pelaksanaannya sering bertabrakan dengan hak kelompok/komunilas ataupun hak keluarga. Meninggalkan agama, sering disamakan dengan meninggalkan haknya sebagai anggota kaum tersebut. Di dalam referensi Islam, keluar dari agama dan berpindah ke agama lain dikenal dengan "murtad" (konversi). Ketiga: Konvesi agama. ${ }^{16}$ Berawal dari kebebasan beragama, masing-masing orang berhak untuk melakukan konversi agama. Ini tentu saja sangat erat sekali dengan hak asasi mereka. Meskipun di sisi lain, berbenturan dengan ajaran agama masing-masing (terutama Islam) yang memandang sikap tersebut (baca: tindakan) sebagai hal yang tercela dan menodai agama (berdosa).

Konversi agama diartikan juga sebagai "reorientation of self atau "part of the general phenomena of personality change". ${ }^{17}$

Konversi agama bukanlah fenomena atau peristiwa yang sederhana. Terdapat "pra condition" yang mendahuluinya dan "post condition" yang mengikutinya. Macam dan tahap yang dilewatipun juga sangat kompleks. Penstiwanya bisa berlangsung dalam skala personal satu atau beberapa orang, juga bisa dalam skala yang lebih luas, kolektif dan merupakan suatu gejala sosial dengan motifmotif sosial pula. ${ }^{18}$ Oleh karena itu konversi dalam pengertian yang terdalam berarti transformasi kepribadian dan kehidupan secara total $^{19}$ yang mengandung dua realitas bertawanan; yaitu "berpaling dari" dan "berpaling kepada" 20 dengan kata lain meninggalkan

${ }^{16}$ Istilah ini diambilkan dalam bahasa Inggris "religions conversion", Lihat: Bernard Spilka (dkk.), The Psychology of Religion: An Empirical Approach, (New Jersey; Prentice Hali Inc., 1985), p. 202. Bandingkan juga dengan: Lester Kurtz, Gods in The Global Village: Trie World Religions in Sociological Perspective, (California: Pine Forgis Press, 1995), pp. 95-96

${ }^{17}$ Bernard Spilka(dkk). ThePsycology.... p. 202

${ }^{18}$ Lihat: Richard "W. Bulliet, "Conversion to Islam and The Emergence of a Muslim Society in Iran", dalara Nehemia Levtzion (ed.), Conversion to Islam, (New York and London: Holmes \& Mejes Publisher, 1979), p. 33.

19 Yohan Devananda, Understanding Conversion in the Context of Dialogue, dajam The Ecumerical Review, World Council of Churches, Vol. 44,1992, p. 434.

${ }^{20}$ John E. Smith, The Concept of Conversion, dalam Walter E. Conn (@d.), Corwersian: Perspectives on Personal ans Social Transformation (New York: AlbaHcuse, 1998), pp. 51-52 
sesuatu yang lama dan berpaling kepada (menerima) sesuatu yang baru.

Konversi agama yang secara umum ditujukan kepada proses yang mengarah kepada penerimaan suatu sikap keagamaan dan menolak sikap keagamaan lain, menurut Spilka terjadi dalam dua bentuk; bertahap (gradual) dan tiba-tiba (sudden) ${ }^{21}$ Proses ini juga mencakup perubahan keyakinan terhadap persoalan keagamaan yang dibarengi dengan perubahan-perubahan dalam motivasi tingkah laku dan reaksi-reaksi terhadap lingkungan sosial. ${ }^{22}$ Menurut Mukti Ali, pada masa penjajahan Belanda rakyat Indonesia yang ketikaituberjumlah 70 jutajiwa, tiga setengah persen darinya berhasil diKristenkan (dikonversikan) ${ }^{23}$, sebagai reaksi terhadap lingkungan sosialnya atau juga disebabkan kondisi ekonomi ketika itu dan tekanan-tekanan sosial yang ada, tetapi di sini bukan berarti menafikan bentuk "sudden" dari konversi karena ukuran gradual dan sudden tersebut akan menjadi sangat relatif.

Dari segi dampaknya, konversi mempengaruhi segenap tindakan sadar dan disengaja seseorang. Menurut Katterine konversi membimbing pandangan, menyerap imajinasi, membebaskan simbol-simbol yang menekan kedalam jiwa. Konversi memperkaya pemahaman-pemahaman, membimbing penilaian-penilaian, dan memperkuat keputusan-keputusan. ${ }^{24}$ Adapun yang dimaksud dengan konversi dalam hal ini, tentu saja sangat memicu sentimen salah satu agama (agama yang ditinggalkan). Meski di sisi lain terdapat keberhasilan agama yang diterima (agama baru) dalam mengkonversikan pemeluk agama lain. Dalam pandangan agama yang ditinggalkannya, omng yang melakukan konversi dikategorikan sebagai pendosa, tidak saleh, dan dangkal pemahaman agamanya (tentang agama yang ditinggalkannya)- Berbeda dengan pandangan agama yang baru

${ }^{21}$ Lihat: Bernard Spilka, dkk. The Psycology..., p. 205. Bandingkan dengan: Earl Fergusen, The. Definition of Religions Conversion, dalam Pastoral Psycology, Vol. 16. No. 156, September, 1965, p. 16. Lihat juga: Walter Houston Clark, The Psycology of Religion, (New York: MacMillan company, 1958Xp- 191.

22 Robert H. Thouless, An Introduction to Psy>cology of Religion, Ed HI, (London: Cambridge University Press, 1971), p. 104.

${ }^{23}$ Lihat: Mukti Ali, Pelbagai Persoalan Islam di Indonesia Dewasa ini, (Yogyakarta: NIDA, 1971), pp. 17-18.

${ }^{24}$ Lihat: Katherine Cassidy, Conversion; Dynamics of the Spiritual Exercise, dalam Review of Religions, Vol. 45, 1986, p. 925. 
dianutnya yang justru sebaliknya dan merupakan awal dari gejala kedewasaan beragamanya.

Keempat: Kesalehan ${ }^{25}$ beragama. Kesalehan secara etimologis berarti baik alau kebaikan. Dalam al-Qur'an kata Shalih sering digunakan untuk memberi sifat terhadap amal perbuatan yang dilakukan seseorang yang beriman. Jika ditarik dalam spektrum yang lebih luas, kata iman yang berarti percaya, apapun bentuk kepercayaannya (Islam, Hindu, Budha, Kristen dan Katolik), semuanya akan membuahkan konsekwensi pada amal yang baik (kesalihan). Sebagaimana yang dijelaskan Masdar FM bahwa kesalihan adalah kualitas bathmiyah tertentu yang dicapai dan dibuktikan melalui proses penghayatan simbol-simbol keagamaan. $^{26}$

Tidak satu agamapun di dunia ini yang bertujuan mencetak pemeluknya sebagai pribadi yang jelek. Semua agama bertujuan membentuk perilaku baik pada pemeluknya dalam rangka menciptakan kedamaian dan ketentraman hidup. Karena dalam setiap agama terdapat dimensi etis, sosial dan penghayatan. ${ }^{27}$ Tetapi masalahnya adalah apakah saleh dalam pandangan agama Kristen juga dipandang saleh dalam agama Islam atau lainnya? Apa ukuran untuk kesalehan itu? Sebab masing-masing agama memberikan ukuran kesalehan bedasarkan ajaran yang dipegang dalam agama tersebut. Barangkali di sinilah sebabnya kenapa muncul keinginan pemerhati masalah agama untuk membentuk etika global. Karena jika tidak kondisi ini rawan sekali terhadap terjadinya ketidakharmonisan dalam masyarakat agama. Sebenarnya, kesalehan beragama tidak lepas dari kedalaman atau kedangkalan agama orang tersebut terhadap ajaran agama yang diyakininya. Mungkin ini dapat menjadi ukuran kesalehan beragama tersebut. Orang yang telah mampu melakukan penghayatan agamanya dengan baik (dalam penghayatan dan pengetahuannya tentang ajaran agamanya) tampak di tengah masyarakat sebagai sosok yang sangat arif yang selalu menebarkan

${ }^{25}$ Lihat: Masdar F. Mas'udi, Antara Kesalihan Individual dan Kesalihan Sosial, dalam M. Masyhur Anun, Moralitas Pembangunan, (Yogyakarta: Pustaka Pelajar, 1994), p. 31.

${ }^{26}$ Lihat: Komaruddin Hidayat, Menemgkap Pesan-pesan Spiritualitas Agama, dalam Harian Kompas, 26 Januari 1994.

${ }^{27}$ Lihat : Ninian Smart, The Religious Experince of Mankind, c\&. II, (New York: Chales Scriber's Son, 1975), pp. 6-10. 
cinta kasih dan kedamaian terhadap sesama, dan lebih lembut dalam berinteraksi dengan orang-orang di luar din dan agamanya.

Sulitnya meletakkan ukuran kedalaman agama seseorang terlihat ketika kita bertemu dengan mereka yang menerapkan pemahaman tentang" agamanya secara ekstrem atau yang bisa disebut dengan fundamentalis. Kedalaman pemahaman mereka tentang ajaran agamanya dapat dikatakan luar biasa dan sebagian terlihat pada penghayatan yang tinggi terhadap ajaran tersebutTetapi terhadap mereka yang berada di luar jalur agama, apalagi terhadap mereka yang tidak beragama, kelompok ini sangat keras dan tidak bertoieransi sama sekali. Di sini timbul pertanyaan apakah ini karena kedalaman agamanya atau karena dangkalnya pemahaman mereka terhadap ajaran agamanya? Ataukah mereka telah keliru dalam memahami agamanya? Padahal sesungguhnya hidup beragama adalah karena ingin menjunjung tinggi nilai-nilai kemanusiaan. Sebagaimana dikatakan Komaruddin Hidayat bahwa hikmah hidup keberagamaan haruslah bermuara pada komitmen untuk menjunjung tinggi nilai-nilai kemanusiaan tanpa harus dihambat oleh kelompok sentimen keagamaan. Jika memang agama diwahyukan untuk manusia dan bukan untuk agama, maka ukuran baik buruknya sikap hidup beragama adalah menggunakan standar dan kategori kemanusiaan, bukan ideologi atau sentimen kelompok. $^{28}$

Beberapa problem agama-agama ${ }^{29}$ di atas sesungguhnya akan menjadi tantangan besar bagi terciptanya dialog antar ummat beragama dan harus ditangani secara serius oleh masing-masing penganut agama. Karena pada dasarnya dialog dibangun atas pertimbangan kemanusiaan yang menuntut terciptanya suasana hidup harmonis antar sesama penganut agama.

\section{Dialog Dalam Sejarah Keberagaman di Indonesia}

Berbicara tentang dialog, sebenaraya syariah telah mencatat bahwa pada pertengahan kedua abad ke-20, tepatnya setelah perang dunia (PD) II, dialog antar agama mulai menjadi salah satu pokok

28 Lihat: Komaruddin Hidayat, Menangkap Pesan-pesan Spiritual Agama, dalam Andito (ed.), Atas Mama Agama, (Bandung: Pustaka Hidayah, 1998), p. 35.

${ }^{29}$ Bandingkan dengan: Problem Agama-agama yang Dipaparkan oleh Roger Trigg, Rasionality and Religion, (Oxford: Blackwell Publisher, ltd. 1998), pp. 49-53. Tetapi Trigg lebih memfokuskan pada truth claim sebagai pokok permasalahan. 
perhatian yang penting di kalangan agama-agama di dunia. Meskipun sebelumnya memang sudah ada dalam bentuk "dialogue of life" alau dialog hidup bersama. Melihat perkembangannya, dapat dikatakan bahwa sampai pada akhir tahun 1992 agamaagama di dunia ini masih berada dalam ketegangan-ketegangan intoleran dan bahkan bermusuhan. ${ }^{30}$ Adalah kenyataan bahwa sampai sekarang agama-agama masih berada dalam banyak ketegangan-ketegangan antar agama tersebut baik disebabkan oleh agama itu sendiri maupun yang terjadi karena faktor-faktor di luar agama, seperti kasus Kristen-Muslim di Pilipina Selatan, SikhHindu dan Muslim di India, Hindu-Budha di Srilangka, KristenMuslim di Libanon, Yahudi dan Arab di Timur Tengah, KatolikProtestan di Irlandia Utara, Muslim-Kristen di kawasan Yugoslavia. Sedangkan di Indonesia sendiri ketegangan antar agama sudah hampir merambah ke seluruh wilayah Nusantara, dan hampir seluruhnya berupa ketegangan antara Muslim dan Kristen.

Di kalangan Kristen, dialog antar agama secara lebih mendalam mulai dibicarakan, dipikirkan dan dilakukan sejak konsili Vatikan II tahun 1961 dan dengan dibukanya sub unit Dialoag Antar Agama oleh Dewan Gereja-gereja sedunia (DGD) tahun 1971. ${ }^{31}$ Di lingkungan Islam sendiri sebenamya dialog seperti yang disebutkan oleh DC. Mulder tersebut sudah ada di masa Rasulullah masih hidup, bukan hanya dialog kehidupan, tetapi Rasulullah juga melakukan dialog secara formal dengan kelompok Yahudi dan Quraisy mengenai perlu hidup berdampingan secara damai dan bertetangga secara baik, bahkan membuat kesepakatan tentang kebebasan menjalankan agama masing-masing. ${ }^{32}$ Sedangkan dalam dunia Islam modern diawali dengan diadakannya kongres Islam se-Dunia di Karachi ${ }^{33}$ tetapi

${ }^{30}$ DC. Mulder, Perkembangan Dialog Antar Agama di Dunia Modern, dalam Th. Sumartana, dkk., Dialog; Kritik..., p. 232.

31 Ibid., Sub Unit tersebut diberi nama "Sub Unit on Dialogue with People of Living Faith (sub unit dialog dengan orang-orang yang menganut kepercayaan yang hidup, awalnya mencakup dialog dengan ideologi-ideologi yang hidup dan berkembang di dunia, tetapi pada tahun 1983 dipisahkan.

32 Baca Umar Hasyim, Toieransi dan kemerdekaaji Beragama Dalam Islam sebagai Dasar Menuju Dialog dan Kerukunan Antar Agama, (Surabaya: Bina Ilrau, 1978), pp. 138-141, Bandingkan dengan: Arief Theria Wasim, Tibyan fi Ma 'rifali alAdyan: Desertasi, Yogyakarta, IAIN Sunan Kalijaga, 1996, pp. 308-3 11.

${ }^{33}$ Op.Cit., p. 232 
tidak mempunyai bagian khusus yang menangani masalah dialog. ${ }^{34}$ Muncul dan Berkembangnya Dialog

Sebenarnya dialog antar umat beragama itu telah dimulai jauh sebelum Yesus lahir di India. Raja Ashoka telah menetapkan sikap terhadap agama lain. Perintah dari Maharaja Emperium pertama dari India pada abad ketiga sebelum masehi dipahat dalam batu cadas, perintah itu sangat mengagumkan karena berisi prinsipprinsip dialog antar agama yang dilakukan tiga abad sebelum masehi. ${ }^{35}$

Untuk konteks keberagamaan di Indonesia, dialog telah pernah dilakukan mulai tahun 1967 atas prakarsa pemerintah dalam bentuk musyawarah yang bertempat di gedung DPA, Jakarta, dihadiri oleh tokoh-tokoh agama dan termasuk tokoh parpol yang berdasarkan agama. ${ }^{36}$ Tetapi dialog semacam ini sempat teputus karena tidak berhasil menetapkan kesepakatan tentang penyiaran agama, baru kemudian pada tahun 1971 diadakan lagi.

Keinginan untuk melakukan dialog sebenarnya sudah mulai nampak setelah meletusnya peristiwa G.30S/PKI, 30 September 1965, dimana keluarga orang-orang komunis dan umat Islam yang miskin menjadi sasaran kegiatan misi Kristen Katolik. Kegiatan misi ini dianggap melanggar kebebasan penganut agama, tidak sesuai dengan asas Pancasila. Pemerinlah mulai mengkhawatirkan kondisi ini, akhirnya pemerintah baru mendapatkan jalan keluarnya pada tahun T967, meski terlebih dahulu diawali oleh peristiwa pembakaran Gereja di Meulaboh Aceh Barat dan Gereja di Makasar. ${ }^{38}$

Sejak tahun 1971 dialog antara pelbagai pemeluk agama di Indonesia diadakan lagi dan terus berjalan sampai sekrang. Dengan menyadari kegagalan yang diakui pada tahun 1967 dan belajar dari pengalaman tersebut, akhirnya dialog antar umat beragama tidak

${ }^{34}$ Lihat: Mukti Ali, Islam dan Pluralitas.- , p. 115.

${ }^{35}$ Ibid

${ }^{36}$ Umar Hasyim, Toleransi..., p. 329. Dihadiri oleh Jendral Soeharto, Meneg Urusan Kesejahteraan Rakyat, Dr. Idham Kholid dan Menteri Agama, K.H. M. Dahlan.

${ }^{37}$ Mukti Ali, IlmuPerbandingan Agama..., p. 83.

${ }^{38}$ Lihat: Sudjargi, Kajian Agama dan Masyarakat: 15 Tahun Badan Penelitian dan Pengembangan Agama, 1975-1990, III, (Jakarta: Depag RE, 1992), pp. 1-3. Pada tahun yang sama juga terjadi pengrusakan sekolah Kristen di Pal Merah Slipi Jakarta. Baca: M. Natsir, Mencari Modus Vivendi antara Ummat Beragama di Indonesia, (Jakarta: Media Dakwah, 1983), p. 7. 
lagi langsung ditangani oleh pemerintah tetapi oleh badan bukan pemerintah dan diikuti oleh banyak pihak. Setelah beberapa kali dan di beberapa tempat diadakan dialog, maka dibentuklah badan konsultasi antar umat beragama yang lebih banyak berbicara tentang berbagai masalah pembangunan yang menyangkut kehidupan umat beragama di Indonesia ${ }^{39}$. Perwujudan dialog di negara kita sebenamya merupakan keinginan bersama untuk membentuk pola hubungan antar umat beragama yang dialogis, dimana secara historis, frekwensi ketegangan dan konflik antar agama mengalami pacang surut (fluktuatif).

Pola Hubungan Antar Ummat Beragama

Pada zaman Majapahit (1389-1520), negeri nusantara ini dihuni oleh penganut agama Hindu, Budha, dan Animisme. Hubungan antar agama terlihat baik dan rukun berkat pendekatan singkretis yang dilakukan oleh penguasa Majapahit. ${ }^{40}$

Berawal dari runtuhnya kerajaan Majapahit (yang beragama Hindu) Islam mulai masuk dan memberikan pengaruhnya yang kuat di tengah masyarakat Hindu-Budha di negeri ini ketika itu, ini ditandai pula dengan berkembangnya kerajaan Malaka (1477-1488) dan Demak (1500-1546) yang menguasai wilayah Sumatera dan Jawa. ${ }^{41}$ Pada masa ini bentrokan antar kerajaan tidak diwamai atas nama agama tetapi karena perebutan wilayah kekuasaan, sampai akhirnya penjajah Belanda datang dengan diboncengi oleh misizending agama Kristen. Usaha ini mendapat dukungan penuh dari pihak Belanda, baik secara moril maupun materiil. ${ }^{42}$

Masuknya Kristen yang dibawa oleh penjajah Belanda ini bukan tanpa konflik atau ketegangan tetapi penjajah Belanda menyadari betul akan terjadinya hal tersebut, oleh karena itu pada masa Belanda ini diterapkanlah suatu kebijakan tentang wilayah penyiaran agama dalam rangka menghindari friksi antar agama. Melalui "pengkaplingan" wilayah kaum penjajah berhasil mengantisipasi ketegangan tersebut. ${ }^{43}$

Perjalanan sejarah yang mencatat hampir tiga setengah abad

${ }^{39}$ Op.Cit.,p.83.

${ }^{40}$ Lihat: Depag Rl, Penerapan Wawasan Nusantara ..., p. 35.

41 Endang Saifuddin Anshari, Wawasan Islam, (Bandung: Pustaka Salman, 1983), p. 217. Untuk tahun kerajaan seluruhnya mengutip dari buku ini.

${ }^{42}$ Ibid., Lihatjuga: Mukti Ali, Pelbagai Persoalan Islam..., pp. 17-18
${ }^{43}$ Depag Rl.,Penerapan Wawasan Nusantara..., p. 36. 
lamanya Belanda menguasai Indonesia, pada akhirnya memunculkan sikap superioritas kelompok Kristen atas agama lain khususnya agama Islam. Upaya imperialisme Belanda ke seluruh Nusantara telah ikut membangun supremasi Kristen untuk misizending mereka, dalam konteks yang lebih tegas dapat dikatakan sebagai usaha kristenisasi yang tentu berjalan sampai pada awal Orde Baru. ${ }^{44}$ Qleh karena itu perlawanan untuk mengusir Belanda, selain untuk meraih kemerdekaan, juga sekaligus sebagai pertikaian antara Muslim dan Kristen di Indonesia. ${ }^{45}$ Meskipun karena semangat nasionalisme tercatat banyak kaum Kristiani pribumi yang ikut berjuang dalam perebutan kekuasaan tersebut. Tetapi setidaknya kondisi ini telah menggambarkan adanya konflik atau ketegangan antara kedua pemeluk agama (Muslim-Kristen) yang akan mengantarkan kita kepada kondisi keberagamaan di masa peralihan revolusi ke Orde Lama.

Sebagaimana diketahui bahwa abad ke sembilan belas disebut juga dengan abad misi, dimana Belanda mulai menancapkan paruhnya di bumi nusantara ini. Terdapat laporan bahwa selama berada di Indonesia (menjajah), Belanda sempat kekurangan tenaga misionaris dan pendeta, lantas mengimpor misionaris dari berbagai negara Eropa yang jumlahnya semakin bertambah terus setelah tahun 1900, para misonaris ini disebar ke seluruh pelosok daerah terutama di Jawa. ${ }^{46}$ Berbagai cara kristiani yang dilakukan kaum misionaris untuk mengurangi kekuatan dan pengaruh Islam. Tetapi mereka menghindari sedapat mungkin konfrontasi langsung, mereka bergerak terutama dalam bidang ekonomi, politik dan pendidikan. Mereka mempromosikan kebiasaan rakyat kuno, adat dan agama rakyat, dialek daerah yang berbeda dengan bahasa Melayu, yang dikaitkan dengan Islam sampai modernisasi perawatan kesehatan dan pendidikan yang akan sedikit demi sedikit mengikis kekuatan Islam. ${ }^{47}$

Terdapat ada semacam konvergensi antara kepentingan kolonial Belanda dan kaum misionaris (yang dianggap kelas dua

${ }^{44}$ Umar Hasyim, Toleransi..., pp. 273-289.

45 Sebagai bukti terdapat slogan-slogan agama Islam dan dikumandangkannya kalimat "Allahu Akbar" dalam beberapa pertempuran

${ }^{46}$ Lihat: Karel Steenbriuk, Kawan Dalam Pertikaian: Kaum Kolonial Belanda dan Islam Indonesia, 1596-1942, terjemahan Suryan A. Jararoh, (Bamhing: Mizan, 1995), pp. 143-80.

${ }^{47}$ Ibid 
oleh kelompok penjajah). ${ }^{48}$ Dalam beberapa hal banyak ketidaksepakatan antara keduanya. Kaum misionans ingin menjujung nilai-nilai kemanusiaan sedangkan penjajah justru sebaliknya. Selain itu juga terjadi perbedaan pandangan tentang agama aktual yang menurut misionaris bukanlah agama Islam tetapi agama rakyat kuno, sebab itu tidak perlu khawatir terhadap Islam, karena Islam juga memberikan sumbangan positif terhadap nilai-nlai kemanusiaan. Kaum misionaris justru berseberangan dengan ajaran "sistem kasta Hindu", pembakaran wanita janda yang masih terjadi pada saat itu di berbagai daerah di nusantara. Di sini terjadi ketegangan dan konflik antara mereka dan penganut agama Hindu yang masih memegang ajaran diatas. ${ }^{49}$

Tahun 1924-1942 adalah merupakan tahun konfrontasi terhebat antara kristen dan muslim. Hal ini berawal dari kegiatan Hendrik Kraemer (1888-1965), salah seorang misionaris yang diposisikan sebagai penasehat perhimpunan mahasiswa "'Jong Java". Ia memberikan kuliah tentang agama Kristen kepada para anggota perhimpunan ini juga tentang teosofi dan katotik. Para mahasiswa muslim yang orthodoks menuntut agar perhimpunan juga mensponsori kuliah tentang Islam, tetapi tuntutan ini ditolak. Akhirnya mereka (mahasiswa muslim) mendirikan "Jong Islamieten Bond". Organisasi ini akhirnya menjadi sebuah organisasi intelektual muda Islam yang percaya diri, yang antara lain dengan gigih menghasut untuk menentang Katolik dan Protestan. ${ }^{50}$

Sebagaimana disebutkan pada bab terdahulu bahwa selama berkuasanya Belanda kelompok mayoritas muslim dianggap sebagai musuh. Hal ini berbeda dengan ketika di masa penjajahan Jepang. Jika Belanda lebih menampakkan sikap anti Islam, Jepang

48 Menurut Lion Cachet salah seorang misionaris yang hidup tahun 1835-1899 Belanda juga mempersulit perizinan dan keuangan misi mereka. Hal ini dianggapnya merusak prestise mereka. Beliau juga seorang misionaris yang sangat keras menolak faham sinkretis.

${ }^{49}$ Ibid, Menurut Corel Poersen, Ketegangan tersebut hanya dalam skala kecil berlangsung lama, (Beliau adalah salah seorang misionaris yang hidup tahun 1836-1919).

50 Ibid., p. 163. Pemimpin Muslim yang mempromosikan pengajaran/kuliah tentang Islam dan keluar dari "Jong Java" adalah H, Agus Salim Organisasi itu juga menerbitkan majalah "Hel Licht" yang bersifat anti Kristen, JIB juga merupakan latar belakang penting bagi para tokoh Masyumi. 
justru menampakkan sikap "bersahabat" terhadap umat Islam. Mereka mengakui betapa pentingnya kedudukan umat Islam dalam negara jajahannya tersebut, meskipun tujuan keduanya adalah sama, yaitu melanggengkan kekuasaannya di negeri ini ${ }^{51}$ Sikap bersahabat penjajah Jepang tersebut terlihat ketika mereka membentuk gerakan Tiga A yang pada bulan Juli 1942 didalam gerakan ini dibentuk sub seksi yang diberi nama Persiapan Persaipan Umat Islam ${ }^{52}$ dan pada 1 Agustus 1944 jabatan Kepala Kantor Urusan Agama (Shwmibu) diserahkan kepada KH Hasyim Asy'ari. ${ }^{53}$ Meski demikian, akhirnya gerakan Tiga A tersebut dibubarkan karena tidak cukup efektif untuk mendukung tujuan mereka dan dibentuklah badan baru beraama Poesat Tenaga Rakyat (Poetera). ${ }^{54}$

Selama masa penjajahan Jepang, friksi dan konflik antar agama sempat surut terutama sejak Jepang membentuk BPUPKI 1 Maret $1945^{55}$, gelombang nasionalisme merambah ke seluruh nusantara. Keinginan bebas dan berdaulat dalam negara yang merdeka secara utuh mengarah kepada perlawanan mengusir penjajah. Isu nasionalisme yang membangkitkan patriotisme kaum pribumi akhirnya terwujud dalam bentuk kemerdekaan penuh dengan habisnya kekuasaan penjajah di negeri nusantara ini. Pada masa revolusi ini, masa eksisnya Orde Lama di bawah kepemimpinan Sukarno, nampaknya ketegangan dan konflik antar agama semakin surut. Meskipun demikian tetap tercatat bahwa ketegangan dan konflik antar ummat beragama sempat menempati posisi yang cukup serius terutama menjelang dan ketika terjadi perdebatan dalam perumusan ideologi (di seputar masalah konstituante).

Ketegangan dan konflik antar agama dimasa rezim Orde Lama tidaklah reda sampai di situ, masalah keagamaan diwariskan kembali kepada rezim Orde Baru, puncaknya adalah isu Kristenisasi dan berbagai usahanya yang berakibat dengan

${ }^{51}$ Anwar Harjono, Perjalanan Politik...,p. 34

52 Tjokroaminoto diangkat sebagai ketua subseksi ini, lihat: MC. Ricklefs, Sejarah Indonesia Modern, alih bahasa Darmono Hardowijono, (Yogyakarta: Gajah Mada University Press, 1991), p. 302.

53 BJ. Boland, Pergumulan Islam di Indonesia, alih bahasa Syaftuddin Bahar, (Jakarta: Graffiti Press, 1985), p. 23.

${ }^{54}$ Lihat: Anwar Harjono, Ferya\&mow..., p. 35.

${ }^{55}$ Ibid., p. 37 
pembakaran beberapa Gereja di Aceh dan Makasar serta sekolah Kristen di Silipi Jakarta. KH Ahmad Dahlan, selaku menteri Agama RI ketika itu bersama dengan Menteri Dalam Negeri Dr. Idham Khalid meletakkan konsep musyawarah antar agama yang pada akhirnya dilanjutkan oleh Mukti Ali sebagai pemangku jabatan kementerian agama setelahnya dengan cara berdialog. Meskipun pada tahun 1967 telah dicanangkan konsep kerukunan umat beragama, nampaknya masa-masa peralihan dan $\mathrm{KH}$. Saifuddin Zuhri sampai berakhirnya jabatan KH. M. Dahlan adalah masa-masa sulit yang selalu terjadi konflik antar agama sebagaimana yang terjadi dewasa ini. Seperti; peristiwa Meulaboh Aceh, Makassar, kasus Slipi, peristiwa pulau Banyak, peristiwa Manado, Flores, peristiwa Donggo, kesemuanya ini terjadi menjelang akhir tahun 1969.

Menyadari akan kondisi keberagamaan yang ruwet seperti hal tersebut dan belajar dari pengalaman-pengalaman masa lain, Mukti Ali dengan gagasan dialognya dengan konsep "agree in disagreement", kelihatannya berhasil menciptakan kondisi harmonis hubungan antar umat beragama di masanya, para tokoh dan ahli agama diajak berdialog untuk ikut serta memperlancar proses pembangunan kala itu. Baliau menerapkan sistem modernisasi polilik keagamaan yang sedikit timpang karena lebih berafilisasi kepada golongan muslim. Penekanan kepada masalah pembangunan menumbuhkan kesadaran akan perbedaan tetapi lebih memperhatikan kesamaan dalam kepentingan, nampaknya adalah resep yang baik bagi harmonisasi hubungan antar umat beragama. Dapat dikatakan di sini bahwa frekwensi ketegangan antar agama tidak lepas dari fluktuasi frekwensi ketegangan perpolitikan yang ada. Secara faktual keragaman partai politik (nuansa ketegangan perpolitikan) pada masa Orde Lama dan awal Orde Baru memberikan bias bagi munculnya banyak ketegangan antar agama, sebaliknya ketika Soeharto berhasil meminimalisir jumlah parpol dan ketegangan dalam perpolitikan, konflik antar agamapun ikut surut.

Pola hubungan antar ummat beragama di Indonesia memang bersifat fluktuatif (pasang surut) dan sangat terkait dengan atmosfer perpolitikan yang ada. Sedangkan untuk melihat tingkat toleransi beragama dalam suatu masyarakat, sebaiknya cukup dengan melihat tingkat pertumbuhan dan keragaman bangunan sarana ibadah yang ada, semakin beragam maka semakin baik hubungan 
antar pemeluk agama yang berbeda di tempat tersebut. Dalam masyarakat yang beragam seperti di atas, kesadaran untuk melakukan dialog tentu saja akan lebih baik. Tetapi perla diingat bahwa dalam setiap agama terdapat kelompok-kelompok yang memahami agamanya secara fanatis dan skriptualis. Bagi kelompok ini dialog dianggap sebagai upaya pendangkalan agama. Dialog dan Militansi Agama

Kaum fanatis ini sering juga disebut dengan kelompok militansi agama $^{56}$ atau sering juga dinamakan tradisionalis skriptualis. Jihad adalah impian bagi kelompok ini dan salah satu sarananya adalah dakwah. Ukuran keberhasilan dakwah bagi mereka adalah keberhasilan dalam mengkonversikan pemeluk suatu agama ke dalam agamanya. Hal itu tidak hanya terdapat di dalam Islam tetapi juga pada agama lain. Pahala adalah imbalan bagi keberhasilan tersebut. Padahal jika kita mau belajar dari masa lalu, karakter dari kegiatan dakwah (misionaris) dalam Islam maupun kristen berpotensi untuk memecah belah. Pengalaman masa lalu menunjukkan menghindari ketegangan-ketegangan di sekitar masalah tersebut, bahkan sekalipun orang-orang datang untuk semangat berdialog, hampir tidak mungkin. ${ }^{57}$

Fanatisme atau fundamentalisme sebagai bentuk dari militansi

${ }^{56}$ Dalam bahasa Azra disebut fundamentalis agama. Baca: Azyumardi Azra, Konteks Bertealogi di Indonesia, (Jakarta: Paramadina, 1999), pp. 133 142. Disebutkan juga bahwa kebangkitan kelompok ini adalah disebabkan juga oleh kerinduan masa lalu (kemurnian agama). Bandingkan juga dengan: Barbara Brown Zikmund, Dialog Agama-Agama Dalam Konteks Misionarisme Baru, dalam Komaruddin Hidayat dan Ahmad AF (ed), Passing Over..., pp. 25-33, lihat juga John keisay dan Simmer B. Twiss, Agama dan Hak-hak Asasi Manusia, terjsmahan Ahmad Suaedy dan Eiga Sarapung, (Yogyakarra: Dian, 1997), pp.33-34. Menurut penulis buku ini bahwa fanatisme agama pada kenyataannya menyebabkan orang dapat dengan mudah melakukan kekerasan demi "agenda" mereka, sebagaimana yang mereka fahami. Penulis buku ini juga mempersamakan antara fanatisme dan fundamentalisme yang kadang-kadang juga disebutnya "militansi agama". Istilah fundamentalisme menurutnya, secara ideologis, teologis maupun historis berhubungan dekat dengan kekristenan. Kata fundamentalisme pertama kali digunakan pada tahun 1920 untuk menyebut suatu pemeluk agama yang taat, yang menunjuk pada suatu gerakan di dalam kekristenan.

57 Lihat: Alwi Shihab, Islam inklusif, (Bandung: Anteve dan Mizan, 1998), p. 96.

52 TAJDID Vol. XIV, No. 1, Januari-Juni 2015 
agama $^{58}$ secara relatif memang mengancam agenda hak-hak asasi manusia. individu maupun kolektif yang pada kenyataannya bertendensi menghidupkan ketegangan antar umat beragama. Mereka mengklaim bahwa dirinya adalah penerus tradisi agama yang sah dan tak berkeputusan. Mereka memberi perlawanan secara kultural, ideologis dan sosial terhadap asumsi-asumsi dan bentuk-bentuk kehidupan yang mapan dalam masyarakat serta kultur sekuler kontemporer dan menolak sepenuhnya sekularisme. Fundamentalisme ini selalu ada dalam setiap tubuh agama baik dalam bentuk faham/pemikiran maupun gerakan. Oleh karena itu John Kelsay dan Sumner B. Twis mengatakan bahwa fundamentalisme tidak mati atau statis melainkan tumbuh terus dan dinamis, tidak mengalami kemunduran dalam pengaruh dengan bangunan solidaritas yang sangat mapan. ${ }^{59}$

Fundamentalisme agama pada dasarnya adalah bentuk lain dari eklusivisme beragama. Karena bangunan solidaritas mereka hanya diperuntukkan kepada iman dan komunitas seiman, mereka menempatkan pjhak lain (di luar agama mereka) pada urutan nomor dua, sulit bagi mereka untuk bisa mendengarkan atau menerima pandangan di luar pemahaman mereka, sebab itu sulit untuk melakukan dialog dengan mereka. Padahal bumi yang kita diami bersama ini dihuni oleh berbagai corak dan ragam watak/sikap keberagamaan, piural masyarakatnya begitu pula agamanya, Perlu kiranya ditanamkan kesadaran akan realitas pluralisme yang tidak terelakkan ini.

Dalam konteks masyarakat Indonesia yang plural ini, kelompok fundamentalIs agama secara nyata memang sulit untuk mengidentifikasinya karena kelompok ini tidak terlembagakan secara parsial dan legal, mereka muncul lebih berbentuk separatis. Mereka mampu survive dalam derasnya gelombang modernisme dewasa ini. Bagi mereka dialog antar agama merupakan "soft bias" dari sekularisasi. Barangkali di sinilah perlunya kita mencari format baru dialog yang dapat diterima semua kelompok.

\section{Format Baru Dialog dalam Masyarakat Majemuk}

Adalah merupakan kesulitan dan sekaligus kenyataan yang harus diterima bahwa ftmdamenlalisme agama dapat eksis

${ }^{58}$ Ibid., Bandingkan juga dengaa istilah radikalisme yang dipakai oleh Alwi Shihab dalam: Alwi Shihab, Islam Inklusif..., pp. 282-286. Dan lihat juga: Azyumardi Azra, Konteks Berteologi-, pp. 89-97.

${ }^{59}$ Baca: John Kelsay . , pp. 35-39. 
sepanjang zaman. Kelompok ini terkadang menjelma sebagai kelompok ekstrem yang sering membuat onar dan kekerasan bahkan di zaman modern ini, tak terkecuali. Menurut Samsul Arifin bahwa fundameotalisme juga dianggap sebagai paradoks post-modenrisme dalam kehidupan keagamaan ${ }^{60}$ yang beipeluang terhadap raunculnya relativisme sebagai sikap dasar dalam mengembangkan dialog-dialog kebenaran, sedangkan fundamentalisme lebih mengutamakan kemapaoan suatu doktrin agama.

Bagi kelompok ini agama difahami untuk diterima dengan sikap "taken for granted" tidak dengan sikap kritis. ${ }^{61}$ Mereka memegang teguh sikap ekslusif dalam beragama seakan-akan tidak menerima perkembangan, dimana mereka sendiri (tanpa sadar) sedang berjalan dalam proses iransformasi tersebut.

Pemahaman manusia terhadap agama sesungguhnya bersifat evolutif. Ada tingkatan-tmgkatannya dimana manusia akan mencapai tingkat kedewasaannya dalam beragama atau yang sering disebut dengan "mayoritas beragama'". Oleh karena itu pemahaman terhadap dogma dan doktrin agama itu berkembang bukan karena sejak awalnya tidak cukup tapi karena manusia itu berkembang, maka pemahaman tersebut tidak akan memadai bila tidak mampu berkembang sejalan. Menrut imam Musawir bahwa Tuhan telah menyampaikan wahyu-Nya kepada manusia pada tingkat evolusinya yang kanak-kanak. Dalam kondisi masih kanak-kanak itu manusia menafsirkan wahyu dan memahaminya dalam bentukbentuk yang terungkap dalam dogma-dogma dan doktrin-doktrin yang menyatakan kepercayaan mereka. Kemudian ketika menjadi matang (dewasa) mereka baru menyadari bahwa pemahaman tersebut tidak mencukupi lagi bagi kondisi keberagamaan di zamannya. $^{62}$

Dalam analisis saya sesungguhnya munculnya problemproblem dalam setiap agama seperti yang disebutkan pada awal bab ini yang lebih bercorak ekslusif, adalah karena tingkat pemahaman dan keberagamaan masih pada tingkat kanak-kanak. Pada tingkat ini keberagamaan seseorang bercorak ekslusif yang

${ }^{60}$ Lihat: Samsul Arifin (dkk), Spirituatilas Islam dan Peradaban Masa Depan, (Yogyakarta: SIPRES, 1996), p. 14

${ }^{61}$ Ibid

${ }^{62}$ Imam Musawir, Posisi Islam di Tengah Pertarungan Ideologi dan Keyakinan, (Surabaya: Bina Ilmu, 1986), pp. 59-60.

54 TAJDID Vol. XIV, No. 1, Januari-Juni 2015 
cenderung mempertahankan absolutisme dan klaim kebenaran agama yang dianutnya. Sehingga peluang unruk dialog menjadi tertutup, padahal di era post modernisme ini kita sudah harus beranjak dari inklusifisme kepada pluralisme yang menjadi ciri posmodernisme itu sendiri. Bahkan jika kita mau mencermati tulisan Paul Waldau tentang kritikannya terhadap Global Ethic (yang bergema inklusif), sesungguhnya Global Ethik itu sendiri telah mengeksklusifkan diri terhadap masalah-masalah di luar human being, sehingga kebutuhan akan dialog bukan lagi atas dasar pertimbangan kemanusiaan tetapi harus realistis (dengan meraberikan perhatian sama terhadap masalah ekologis). ${ }^{63}$

Format dialog yang lebih menekankan kepada aspek "Humanitas" (pertimbangan kemanusaan) di era Pluralisme beragama ini, seharusnya sudah mulai kita tinggalkan menuju horizon baru yakni "Supra Pluralisme" ${ }^{64}$ dimana ciri-cirinya adalah bukan lagi penekanan terhadap dimensi kemanusiaan tetapi menjadi keberimbangan aspek Humanis dan ekologis, karena bumi ini tidak hanya dihuni oleh manusia tetapi juga oleh mahluk lain seperti tumbuh-tumbuhan binatang dan alam. Dari sini dapat difahami bahwa ukuran nilai keberagaman itu bukan lagi dengan standar kemanusiaan tetapi juga standar ekologis. Keberagaman dari kedua aspek inilah yang menjadi dasar bagi kedewasaan beragama seseorang, sehingga dialog tidak hanya berimplikasi positif terbadap manusia tetapi juga terhadap lingkungan/ekologi (tumbuh-tumbuhan, hewan dan alam), sebab itu dialog tidak dapat dilakukan kecuali oleh mereka yang telah mencapai tingkat kedewasaan dalam beragama.

\section{Azas Agree in Disagreement}

Dalam konteks Pluralisme beragama dan bermasyarakat di Indonesia, sesungguhnya kita telah merambah masuk kedalam horizon suprapluralisme dimana agama telah menjadi "'dialectical Totality" yang telah harus bersinggungan dengan seluruh aspek kehidupan secara dialogis. Kita tidak bisa lagi berpandangan sempit dalam memahami agama karena yang paling penting dalam keberagaman sebagaimana dikatakan Romo Mangun adalah bukan

${ }^{63}$ Lihat: Paul Waldan, Inter Faith Dialogue Need an Inclusive Global Ethnic, dalam World Faiths Eacxaunter, No- 34, July, 1996.

${ }^{64}$ Istilah ini diambil dari tulisan: Arselm Kyongsuk Min, Dialectical Pluralism and Solidarity of others: Toward a New Paradigma, daJara Journal of American Academy of religion (AAR) 65-13, p.591. 
"to have a religion" akan tetapi "being religius"65 yang akan memungkinkan terjadinya toleransi eukumenik dan menghindari pemberhalaan agama yang menutup adanya dialog dengan agama universal. Disinilah letak signifikasi dari kehadiran Posmiodemisme yang pada dasarnya ingin menolak semua pemberhalaan tersebut serta mendorong terbukanya dialog-dialog yang lebih demokratis.

Banyak teori-teori yang dilontarkan oleh para ilmuan agama dalam menyikapi konteks Pluralisme beragama dewasa ini, antara lain teori yang diajukan oleh Mukti Ali yang menyatakan "Agree in Disagreement" (setuju dalam perbedaan). ${ }^{66}$ Inilah yang menurut Beliau konsep yang paling baik dipegang untuk menimbulkan kerukunan hidup beragama. Dengan berpegang pada prinsip ini, dialog akan berjalan lancar dan baik. Lancarnya dialog antar umat beragama di Indonesia sangat dibantu oleh pengetahuan ummat tentang agama-agama salah satunya adalah melalui ilmu perbandingan agama. $^{67}$

Lebih jauh beliau menjelaskan konsep ini bahwa orang yang beragama harus percaya bahwa agama yang ia peluk itulah agama yang paling baik dan paling benar dan tetap mempersilahkan orang lain untuk mempercayai bahwa agama yang dipeluknya adalah agama yang paling baik. Sebab apabila orang itu tidak percaya bahwa agama yang ia peluk itu adalah agama yang paling benar dan baik, maka adalah suatu kebodohan untuk memeluk agama itu. Dengan keyakinan bahwa agama yang ia peluk itu adalah agama

${ }^{65}$ Baca : Samsul Arifin (dkk),Spiritualitas...,p. 16.

66 Satu-satunya tulisan yang menyatakan bahwa teori tersebut merupakan gagasan dari Mukli Ali adalah Umar Hasyim, Toleransi...., p. 358. Selain dari tulisan ini tidak ada yang menyatakan secara ekplisit bahwa teori tersebut merupakan gagasan Mukti Ali, beliau sendiri ketika berbicara tentang teori ini selalu diawali dengan menyatakan "...pemikiran yang diajukan orang-orang..." tidak dengan menawarkan langsung bahwa teori itu darinya, lihat: Burhanuddin Daya dan Herman Leonard Back (red) Ilmu Perbandingan ..., pp.226-231. Lihat juga: Mukti Ali, Memahami beberapa aspek..., p. 60-62. Menurut Tarmizi Taher ungkapan agree in disagreement (setuju dalam perbedaan) lahir dari dialog-dialog yang digelar semasa kepemimpinan Mukti Ali sebagai Menag RI. Lihat: Tarmizi Taher, menuju lapangan Banteng: kenangan bersama pak Munawair dalam Muhammad Wahyuni Nafis, dkk(ed), kontekstualisasi ajaran Islam; 70 tahun Munawir Sadzali (Jakarta; Paramadina, (1995). p. 138

${ }^{67}$ W.A.L Stakhol, Perbandingan Agama..., p. 10. 
yang paling benar dan baik, maka timbullah kegairahan untuk berusaha supaya tindak laku lahir sesuai dengan ucapan hatinya (bathiniyah) yang merupakan dorongan agama yang ia peluk. Seseorang harus meyakini bahwa disamping perbedaan yang terdapat diantara satu agama dengan agama yang lain, masih banyak terdapat persammaan-persamaannya. Dan berdasarkan pengertian itulah sikap saling hormat menghormati, saling harga menghargai di tumbuhkan antar sesama pemeluk agama. Lantas dari sinilah kerukunan hidup beragama dapat diciptakan. ${ }^{68}$

Menurut Mukti Ali satu-satunya konsep yang paling tepat untuk menciptakan kerukunan umat beragama di Indonesia adalah konsep agree in disagreement tersebut, dimana salah satu wadah aktualisasi dan sosialisasinya melalui dialog. Beliau juga memberikan pandangan beliau tentang konsep-konsep lain yang diajukan para tokoh agama, seperti konsep sinkretisme, reconception, sintesis dan penggantian yang menurutnya untuk konteks keberagaman bangsa Indonesia adalah tidak tepat ${ }^{69}$ Alasan beliau untuk menolak konsep-konsep diatas adalah sebagai berikut; konsep Sinkretisme tidak dapat di terima, sebab dalam ajaran Islam umpamanya, Khalik lain dengan makhluk. Zat yang menciptakan lain dengan yang diciptakan. Antara Khalik dan makhluk harus ada pemisah dan harus ada batas supaya dengan demikian jelas siapa yang disembah dan untuk siapa orang-orang berbakti. ${ }^{70}$ Karena konsep ini merupakan suatu pandangan hidup yang tidak melihat adanya garis batas antara Tuhan dengan yang diciptakannya. ${ }^{71}$

Konsep "reconception" yang artinya menyelami dan meninjau kembali agama sendiri dalam konfrontasinya dengan agama-agama lain. Tokohnya adalah W.E. Hocking, pemikirannya diuraikan dalam bukunya Living Religious and A World Faith dan The Coming World Civilization. Konsep ini bertujuan menyusun suatu agama universal (umum) yang memenuhi kebutuhan segala orang dan bangsa yang didasarkan pada pandangan bahwa semua agama adalah sama. Ini tidak dapat diterima. Karena dengan jalan itu agama merupakan produk pemikiran manusia, sedangkan agama sebenarnya adalah wahya, bukan akal yang menciptakan agama,

${ }^{68}$ Mukti Ali, Mememahami ., pp. 61-62

69 ibid, pp. 58-61. Lihat juga: Burhanuddin Daya dan Herman leonard Back (ed.), Perbandingan ..., pp. 228-230.

${ }^{70}$ Ibid

${ }^{71}$ Op.Cit, p.59. 
tetapi agamalah yang memberikan bimbingan kepada manusia untuk mempergunakan akalnya. Sedangkan dengan konsep "sintesis" juga tidak dapat diterima. Agama sintesis itu sendiri tidak dapat diciptakan karena tiap-tiap agama mempunyai latar belakang sejarahnya tersendiri yang tidak begitu saja dengan gampang diputuskan. Tiap-tiap agama terikat dengan hukum-faukum sejarahnya. Adapun jika konsep "penggantian" atau disebut dengan konversionisme yang diambil, juga tidak bisa. Kita hidup dalam masyarakat serba ganda (plural society); ganda dalam segala aspek kehidupan manusia termasuk ganda dalam pengertian terhadap motivasi dan fungsi perbuatan manusia, jalan "penggantian" ini justru akan menimbulkan intoleransi. Karena akan terjadi tarikmenarik untuk mengikuti agama dan mempertahankan agama yang menjadi pengganti. ${ }^{72}$

Sebelum membicarakan tentang konsep agree in disagreement, di sini saya ingin mengatakan kesamaan pandangan terhadap empat konsep yang ditolak Mukti Ali di atas. Konsep sinkretisme justru mengkaburkan identitas pemeluk suatu agama. Kita akan sulit membedakan pemeluk suatu agama dengan yang lain dalam keberagamaannya. Implikasi yang paling ekstrem adalah munculnya gejala atheisme yang dalam sepanjang sejarahnya ditolak keras oleh bangsa kita, sedangkan ketiga konsep lain juga tidak menyelesaikan masalah, dan justru sebaliknya menambah komplek permasalahan dimana pada dasarnya seluruh agama akan mempertahankan eksistensi agamanya. Kehadiran agama baru dan meninggalkan agama yan dianggap usang justru akan menjadi tandingan bagi agama-agama yang bertahan tersebut.

Dalam kontek keberagamaan di Indonesia, konsep yang ditawarkan Mukti Ali memang sudah cukup tepat meskipun masih dalam tatanan inklusivisme beragama, belum mengarah kepada pluralisme beragama. Tetapi di sini saya ingin mengatakan bahwa sesungguhnya konsep tersebut merupakan refleksi dari pemahaman terhadap motto resmi Negara Republik Indonesia; BHINEKA TUNGGAL IKA yang berarti "persatuan dalam perbedaan". Jika tidak ingin mengatakan bahwa konsep tersebut adalah ungkapan lain dari motto di atas. Munculnya konsep di atas baru ketika Muki Ali menjabat sebagai Menteri Agama dimana pada saat itu pemerintah berupaya membangun dalam segala aspek kehidupan

${ }^{72}$ Ibid., p. 61

58 TAJDID Vol. XIV, No. 1, Januari-Juni 2015 
terutama ekonomi. Selaku tangan pemerintah yang menangani sektor agama, beliau terbebani untuk menyelaraskan masalah agama dengan pembangunan, dimana Pancasila harus dijadikan asas dalam setiap geraknya dan hal ini tidak bisa dilepaskan dan motto Bhineka Tunggal Ika yang telah lama diletakkan oleh The Founding Fathers kita sebagai konsep dalam berbangsa dan bernegara, dan ini tentu saja sekaligus sebagai konsep beragama, karena negara kita adalah negara yang mewajibkan setiap warganya untuk menganut satu agama yang diakuinya. Selain itu jika kita melihat besaraya keterpengaruhan Mukti Ali oleh pemikiran Joachim Wach terutama dalam bidang perbandingan agama. Secara implisit, sesungguhnya Joachim Wach telah menyebutkan bahwa ada sejumlah cara untuk menjadi agamis yaitu mengenal dan menyembah Tuhan, karena dalam keberagamaan terdapat adanya perbedaan yang harus disadari dengan tetap berpegang teguh pada keyakinan bahwa kebenaran ada dalam agamanya tanpa mengabsolutkan agama itu sendiri. ${ }^{73}$ Dan yang paling penting adalah bahwa Joachim Wach tidak pernah memahami toleransi agama sebagai ketidak-perbedaan agama. ${ }^{74}$

Dari sini dapat dilihat bahwa hampir keseluruhan pemikiran Joachim Wach dalam bidang ilmu perbandingan agama dan metodologinya disadur oleh Mukti Ali, selain beliau juga sangat dipengaruhi oleh Wilfred Cantwel Smith dalam bidang Metodologi Studi Agama (Islam). Oleh karena itu saya punya alasan kuat untuk mengatakan bahwa konsep "agree in disagreement", istilah konep tersebut memang dari Mukti Ali sedangkan substansi makna dan pengertian sudah dapat dipahami (terdapat) di dalam motto Bhineka Tunggal Ika dan pemikiran Wach tersebut.

Memasuki era post modernisme dimana kita sudah harus beranjak dari pluralisme menuju suprapluralisme dan mengingat kondisi bangsa yang kian hari disibukkan oleh konflik-konflik yang bersifat vertikal maupun horisontal dan akan sangat mengancam disintegrasi sosial bangsa kita, sesungguhnya banyak teori yang secara relevan dilontarkan oleh kaum pluralis dalam memberikan jalan keluar bagi kondisi keberagamaan khususnya, dimana kondisi disharmoni ini terjadi dihampir seluruh negara di dunia. Teori-teori

${ }^{73}$ Baca: Josep M Kitagawa (peny.), Ilmu Perbandingan Agama: Bentuk Pengalaman Keagamaan Joachim Wach, terjemahan Djam'annuri, (Jakarta: Raja Grafindo Persada, 1996), pp. I dan II

${ }^{74}$ Ibid., p. XL 
tersebut antara lain seperti yang ditawarkan oleh Raimundo Pannikar dengan paralelisme dan pluralismenya, ${ }^{75}$ dan Anselm Kyongsak Min dengan konsep pluralisme dialectisnya. ${ }^{76}$

\section{Penutup}

Kehadiran pluralisme dan kesadaran akan realitas plural yang tidak dapat dipungkiri, apalagi untuk dihindari, merupakan momentum dimana signifikansi dialog antar ummat beragama semakin dirasakan. Tetapi di sisi lain kemungkinan munculnya gajala relativisme akan semakin besar. Hal paling mendasar adalah meletakkan standar bagi nilai keberagamaan seseorang. Apabila dikaitkan dengan wacana dialog, maka sesungguhnya standar atas nilai keberagamaan tersebut adalah kedewasaan (maturitas), karena dialog itu sendiri adalah maturitas atau kedewasaan. Oleh karena itu, dialog itu sendiri hanya akan mencapai hasilnya bila pihak yang berdialog sudah mencapai taraf kedewasaan dalam keberagamaannya. Melalui kedewasaan beragama (sebagai pendekatan) diharapkan kondisi keberagamaan dalam pluralisme beragama akan semakin sehat dan sportif.

\section{Daftar Pustaka}

Ali, Mukti. "Agama, Moralitas dan Perkembangan Kontemporer," dalam Mukti Ali, dkk, Agama dalam Pergumulan Masyarakat Kontemporer, Yogyakarta; Tiara Wacana, 1997.

Anshari, Endang Saifuddin. Wawasan Islam, Bandung: Pustaka Salman, 1983.

Arifin, Samsul (dkk). Spiritualitas Islam dan Peradaban Masa Depan, Yogyakarta: SIPRES, 1996.

Azra, Azyumardi. Konteks Bertealogi di Indonesia, Jakarta: Paramadina, 1999.

Boland, BJ. Pergumulan Islam di Indonesia, terj. Syafiuddin Bahar, Jakarta: Graffiti Press, 1985.

Cassidy, Katherine. "Conversion; Dynamics of the Spiritual Exercise," dalam Review of Religions, Vol. 45, 1986.

Clark, Walter Houston. The Psycology of Religion, New York: MacMillan company, 1958.

Dqaitra, Oka. Kuliah Agama Budha untuk Perguruan Tinggi, Jakarta: YASADARI, 1996.

Hasyim, Umar Toleransi dan kemerdekaaji Beragama Dalam

\footnotetext{
${ }^{75}$ Baca: Raimundo Pannikar, Dialog Intro.... p. 158.

${ }^{76}$ Anselm KyongsukMin, Dialectical Pluralism..., p. 587-588.
} 
Islam sebagai Dasar Menuju Dialog dan Kerukunan Antar Agama, Surabaya: Bina Ilrau, 1978

Heuken Sj., Adolf. Ensiklopedi Gereja I, A-G, (Jakarta: Yayasan Cipta Loka Caraka, 1991), pp. 240-241.

Hidayat, Komaruddin dan Ahmad Gaus AF (ed.) Passing Over Melintasi Batas Agama, Jakarta: Gramedia Pustaka Utama dan Paramadina, 1998.

------, "Menangkap Pesan-pesan Spiritual Agama," dalam Andito (ed.), Atas Nama Agama, Bandung: Pustaka Hidayah, 1998.

------, dan M. Wahyuni Nafis. Agama Masa Depan: Jakarta: Paramadina, 1995.

------, "Menangkap Pesan-pesan Spiritualitas Agama," dalam Harian Kompas, 26 Januari 1994.

Keisay, John dan Simmer B. Twiss, Agama dan Hak-hak Asasi Manusia, terj. Ahmad Suaedy dan Eiga Sarapung, Yogyakarta: Dian, 1997.

Ketsay, John dan Summer B. Twis. Agama dan Hak-hak Asasi Manusia, terjemahan Ahmad Suaedy dan Elga Sarapung, (Yogyakaita: Dian Interfei, 1997.

Kitagawa, Josep M. (peny.), Ilmu Perbandingan Agama: Bentuk Pengalaman Keagamaan, terj. Djam'annuri, Jakarta: Raja Grafindo Persada, 1996.

Kurtz, Lester. Gods in The Global Village: Trie World Religions in Sociological Perspective, California: Pine Forgis Press, 1995.

Mas'udi, Masdar F. "Antara Kesalihan Individual dan Kesalihan Sosial," dalam M. Masyhur Anun, Moralitas Pembangunan, Yogyakarta: Pustaka Pelajar, 1994.

Mukti Ali, Pelbagai Persoalan Islam di Indonesia Dewasa ini, Yogyakarta: NIDA, 1971.

Musawir, Imam. Posisi Islam di Tengah Pertarungan Ideologi dan Keyakinan, Surabaya: Bina Ilmu, 1986.

Natsir, M. Mencari Modus Vivendi antara Ummat Beragama di Indonesia, Jakarta: Media Dakwah, 1983.

Richard "W. Bulliet, "Conversion to Islam and The Emergence of a Muslim Society in Iran", dalam Nehemia Levtzion (ed.), Conversion to Islam, New York and London: Holmes \& Mejes Publisher, 1979.

Ricklefs, MC. Sejarah Indonesia Modern, terj. Darmono Hardowijono, Yogyakarta: Gajah Mada University Press, 1991. 
Spilka, Bernard (dkk.) The Psychology of Religion: An Empirical Approach, New Jersey; Prentice Hali Inc., 1985.

Smith, John E. "The Concept of Conversion," dalam Walter E. Conn (@d.), Corwersian: Perspectives on Personal ans Social Transformation (New York: AlbaHcuse, 1998), pp. 51-52

Shihab, Alwi. Islam inklusif, Bandung: Anteve dan Mizan, 1998.

Smart, Ninian. The Religious Experince of Mankind, c\&. II, New York: Chales Scriber's Son, 1975.

Sudjargi, Kajian Agama dan Masyarakat: 15 Tahun Badan Penelitian dan Pengembangan Agama, 1975-1990, III, Jakarta: Depag RE, 1992.

Steenbrink, Karel Kawan Dalam Pertikaian: Kaum Kolonial Belanda dan Islam Indonesia 1596-1942, terj. Suryan A. Jararoh, Bandung: Mizan, 1995.

Thouless, Robert H. An Introduction to Psycology of Religion, Ed HI, London: Cambridge University Press, 1971. 